Article

\title{
Selection and Validation of Appropriate Reference Genes for Real-Time Quantitative PCR Analysis in Needles of Larix olgensis under Abiotic Stresses
}

\author{
Dandan $\mathrm{Li}^{\dagger}$, Sen $\mathrm{Yu}^{\dagger}$, Minzhen Zeng, Xiao Liu, Jia Yang and Chenghao Li * \\ State Key Laboratory of Tree Genetics and Breeding, Northeast Forestry University, Harbin 150040, Heilongjiang, \\ China; dandanli0317@163.com (D.L.); yusen13624680345@163.com (S.Y.); zeng13218491325@163.com (M.Z.); \\ buxiaobu188@163.com (X.L.); 18845162480@163.com (J.Y.) \\ * Correspondence: chli0@163.com \\ † These authors contributed equally to this work.
}

Received: 15 January 2020; Accepted: 5 February 2020; Published: 10 February 2020

\begin{abstract}
Larix olgensis Henry is an important afforestation species in northeastern China because of its fast juvenile growth, high-quality timber, and significant economic and ecological values. The selection of appropriate reference genes is necessary for the normalization of gene expression determination during quantitative real-time polymerase chain reaction (qRT-PCR) experiments. In this study, qRT-PCR was used to study gene expression. Three software packages geNorm, NormFinder, BestKeeper were used, and a comprehensive ranking of candidate reference genes was produced based on their output to evaluate the expression stability of 16 candidate reference genes from L. olgensis under drought, salt, cold, and heat stress. PP2A-1 and GAPDH ranked as the most stable reference genes under drought and cold stress, $P P 2 A-1$ and $U B Q 10$ were most stable under salt stress, and TIP41 and ACT2 were most stable under heat stress. The least stable gene was $A D P$, which ranked the last under all treatments. Expression profile analysis of the antioxidant gene $C A T$ using the two most stable and the single least stable reference genes under each stress further verified that the selected reference genes were suitable for gene expression normalization. This study provides an important foundation for the selection of suitable reference genes for the normalization and quantification of L. olgensis gene expression under abiotic stress conditions.
\end{abstract}

Keywords: Larix olgensis; reference gene; qPCR; abiotic stress; gene expression

\section{Introduction}

Gene expression analysis is an important tool for identifying key genes and understanding complex biological processes such as metabolic pathways, signal transduction, and plant development. Quantitative real-time polymerase chain reaction (qRT-PCR) is the most effective, simple, specific, inexpensive, and sensitive method for quantifying the expression of target genes [1,2]. Nevertheless, various factors such as RNA integrity, reverse transcription efficiency, cDNA quality, primer specificity, amplification efficiency, and the selection of reference genes (RGs) may significantly influence the reliability of qRT-PCR results [3,4]. Selection of inappropriate RGs will introduce inaccuracies into the experimental data, and screening for one or more suitable RGs is therefore important for the normalization of gene expression data.

Previous literature has described the selection of RGs for various species under different biotic and abiotic stresses and in different development stages and tissues. These species include Arabidopsis thaliana [5], Oryza sativa [6], Solanum lycopersicum [7], Malus domestica [8], and Populus euramericana cv [9]. RGs are often housekeeping genes that are associated with basic cellular processes and 
therefore expressed at a constant level under different experimental conditions [10]. Glyceraldehyde 3-phosphate $(G A P D H)$, actin $(A C T)$, ubiquitin $(U B Q)$, ubiquitin conjugating enzyme (UBC), 18SrRNA, elongation factor 1 alpha $(E F-1 \alpha)$, eukaryotic translation initiation factor $4 \alpha(e I F-4 \alpha)$, tubulin beta (TUB), and alpha-tubulin (TUA) genes have frequently been used as RGs to standardize the expression of target genes [11]. In Lactuca sativa, LsPP2A-1 (protein phosphatase 2A-1), LsPP2AA3 (protein phosphatase 2A regulator subunit A3), and LSTIP41 (TAP42-interacting protein of $41 \mathrm{kDa}$ ) genes were found to be the most suitable RGs in both diurnal and developmental time course experiments [12]. In Petroselinum crispum, the most stable genes under abiotic stress were $E F-1 \alpha$ and $T U B$, whereas the most stable genes under hormone stimulus treatments were $E F-1 \alpha, G A P D H$, and TUB [13]. ACT2, UBC9, PP2A-1, and $P T B P 1$ were the most stable RGs under a variety of experimental treatments, and $A C T$ and TUB have been used as RGs for qRT-PCR normalization in Salix matsudana under salt and copper stress [14]. In addition, recent studies have indicated that stably expressed RGs in one species may not be suitable for other species and may not be universally suitable under all treatment conditions $[15,16]$. Although some genes have been selected as good references, the expression of these housekeeping genes in different organs, developmental stages, physiological states, and stress conditions is unknown $[17,18]$. For example, TUB and TUA ranked as optimal RGs in P. crispum at different development stages [13]; however, in Cucumis sativus, TUA showed the lowest stability under long-term heavy metal and drought stress [19]. Therefore, the selection of suitable RGs for a specific experimental design or species is very important. However, previous research has focused primarily on herbaceous plants and broadleaf trees; whether universal RGs exist for Larix olgensis remains unclear.

L. olgensis Henry is an important timber species that is widely distributed in northeastern China, eastern Russia, and North Korea [20]. It is an important afforestation species because of its fast juvenile growth, high-quality timber, and ability to tolerate severe environmental stresses like drought and extreme temperatures [21,22]. L. olgensis produces wood for lumber, paper, pulp, and biofuel and has significant ecological and economic values [21,23]. In recent years, genetic engineering has been applied to coniferous forest species. Genomic and transcriptomic resources for L. olgensis have been developed, and several genes related to biotic stress response have been identified [24]. An analysis of the transcriptomes of two hybrid larch (Larix kaempferi $\times$ L. olgensis) clones showed that genes related to stress response may play an important role in adventitious root development [25]. Four L. olgensis MYB transcription factors have been identified and shown to have a potential role in xylem development [26]. Expression characteristics of several stress-related L. olgensis genes have been the subject of preliminary study. For instance, LoMYB29 was expressed when induced by MeJA, ABA, NaCl, drought, wounding, and high light [27]. Ectopic expression of LoERF017 from L. olgensis in A. thaliana enhanced its salt and osmotic-stress tolerance [28]. In other timber species like Cunninghamia lanceolata, Chen et al. selected RGs in roots as material under water, phosphorus, and nitrogen stresses [29]. As we know, nitrogen (N) starvation/toxicity involves important protecting molecules, such as polyamines which influence yield and productivity of timber species [30]. Nevertheless, as these studies show, the traditional housekeeping gene TUA is the only RG that has been used to validate L. olgensis gene expression. Therefore, more appropriate RGs are required for the normalization of L. olgensis gene expression, particularly under different stress conditions.

Recently, the available transcriptome data from L. olgensis has increased, providing a foundation from which to identify sets of optimal RGs. In this study, we selected 16 candidate RGs from L. olgensis transcriptome sequencing data and evaluated their expression in response to drought, salt, heat, and cold stress. The software packages geNorm, NormFinder, BestKeeper and comprehensive analysis were used to analyze the expression stability of candidate RGs. We then selected a target gene, $C A T$, which was used to evaluate the reliability of candidate RGs under stress treatments [31]. This study will provide useful information for the selection of suitable RGs for normalization of L. olgensis gene expression under abiotic stress. 


\section{Materials and Methods}

\subsection{Plant Materials and Treatments}

Mature seeds of L. olgensis Henry were collected from the Qingshan Forestry Bureau Seed Orchard in Heilongjiang Province and sown in plastic pots $(11 \times 11 \mathrm{~cm})$ containing a vermiculite/soil mixture (1:1) and cultured in a growth chamber with $70 \%$ relative humidity under a 16-h/8-h light/dark photoperiod with a light intensity of $150 \mu \mathrm{mol} \mathrm{m} \mathrm{m}^{-2} \mathrm{~s}^{-1}$ [27]. Three-month-old seedlings with consistent growth were selected for abiotic treatments. For salt and drought experiments, pots were irrigated with $0.2 \mathrm{M}$ $\mathrm{NaCl}$ or $20 \%$ PEG 6000 solutions for $0,2,6,12$, and $24 \mathrm{~h}$. Plants were irrigated every $12 \mathrm{~h}$ during the experiment. For heat and cold stress treatments, three-month-old seedlings were transferred into light incubators and exposed to 40 or $4{ }^{\circ} \mathrm{C}$ for $0,2,6,12$, and $24 \mathrm{~h}$ [32]. All the treatments were performed with three biological replicates. Needles were carefully harvested from treated and untreated plants, frozen immediately in liquid nitrogen, and stored at $-80{ }^{\circ} \mathrm{C}$ for RNA extraction.

\subsection{RNA Extraction and cDNA Preparation}

Total RNA was isolated using the CTAB (cetyltrimethylammonium bromide) method [33]. The concentration of extracted RNA was quantified using a P300 ultramicro spectrophotometer (IMPLEN, Munich, Germany) and evaluated by $0.8 \%$ agarose gel electrophoresis. Next, cDNA synthesis was performed using RNA samples with A260/A280 ratios between 1.8 and 2.0 and A260/A230 ratios higher than 2.0. Approximately $1000 \mathrm{ng}$ of total RNA was used to be reversely transcribed into cDNA with the TransScript ${ }^{\circledR}$ II One-Step RT-PCR SuperMix (TransGen Biotech, Beijing, China). The cDNA was serially diluted $\left(10^{-1}, 10^{-2}, 10^{-3}, 10^{-4}, 10^{-5}\right.$, and $\left.10^{-6}\right)$ for determination of the correlation coefficient $\left(\mathrm{R}^{2}\right), \mathrm{R}^{2}$ and slope values were obtained from the standard curves, and the amplification efficiency (E) calculated according to the formula: $\mathrm{E} \%=\left(10^{-1 / \text { slope }}-1\right) \times 100 \%$; it was diluted 10 -fold for qPCR analysis and stored at $-20^{\circ} \mathrm{C}$ until further use.

\subsection{Selection of Candidate Reference Genes and Primer Design}

This study took advantage of the unpublished L. olgensis genome information generated by our team: we had previously analyzed transcriptome for this species with and without watering (unpublished). We screened candidate reference genes according to the following criteria: the fragments per kilobase of exon model per million mapped reads (FPKM values) were appropriating in all samples, and the coefficient of variation (CV) of FPKM value was cut off less than 0.5. Based on previous studies the criteria, 16 commonly used reference genes including glyceraldehyde 3-phosphate dehydrogenase $(G A P D H), 18 S$ ribosomal RNA (18S), actin 2 (ACT2), tubulin beta-6 (TUB), eukaryotic translation

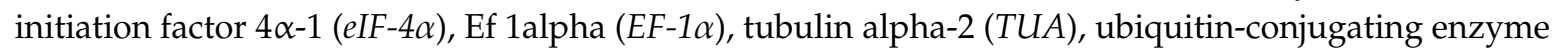
9 (UBC9), TIP41-like protein (TIP41), protein phosphatase 2A-1 (PP2A-1), polyubiquitin 10 (UBQ10), polypyrimidine tract binding protein (PTBP1), ADP-ribosylation factor (ADP, or ARF), histone (HIS), ubiquitin-like protein RUB2 (UBQ7), and actin protein coding 12 (ACT12) genes were used as candidate genes to identify the most stable RGs under different treatments. Detailed information on each gene is presented in Table 1. The coding sequences (CDs) of the 16 Arabidopsis genes were downloaded from the TAIR database (http://www.arabidopsis.org) to identify their homologs in the L. olgensis transcriptome. The Bioedit Sequence Alignment Editor was used to perform a local BLAST to conduct the blastn search of the L. olgensis transcriptome using the Arabidopsis query sequences. We identified 16 candidate RGs and one target gene, CAT (Table 2). The CDs sequences from the L. olgensis transcriptome were submitted to GenBank. Primer5 was used to design specific primers for each gene using the following criteria: GC content $44 \%-60 \%$, optimal Tm 58-60 ${ }^{\circ} \mathrm{C}$, primer length $20-22 \mathrm{bp}$, and amplicon length 80-220 bp (Table 2). The specificity of all primer pairs was checked by standard PCR using cDNA as a template with KOD FX (Toyobo, Osaka, Japan), and amplified products were verified with $2 \%$ agarose gel and sequenced to confirm their identity. 
Table 1. Selected candidate reference genes used in quantitative real-time polymerase chain reaction (qRT-PCR) analysis, with information on their Arabidopsis homologs.

\begin{tabular}{|c|c|c|c|c|c|}
\hline Gene & $\begin{array}{l}\text { Accession } \\
\text { Number }\end{array}$ & Description & $\begin{array}{l}\text { Arabidopsis } \\
\text { Homolog } \\
\text { Locus }\end{array}$ & E-Value & Identities \\
\hline GAPDH & MN905721 & $\begin{array}{c}\text { Glyceraldehyde 3-phosphate } \\
\text { dehydrogenase }\end{array}$ & AT1G13440 & $4 \times 10^{-81}$ & $80 \%$ \\
\hline $18 \mathrm{~S}$ & MN905722 & $18 \mathrm{~S}$ ribosomal RNA & AT2G47420 & 0.005 & $88 \%$ \\
\hline ACT2 & MN905723 & Actin 2 & AT3G18780 & $4 \times 10^{-141}$ & $80 \%$ \\
\hline TIP41 & MN905724 & TIP41-like protein & AT4G34270 & $4 \times 10^{-15}$ & $84 \%$ \\
\hline$E F-1 a$ & MN905725 & Elongation factor 1-alpha & AT5G60390 & $4 \times 10^{-101}$ & $81 \%$ \\
\hline TUB & MN905726 & Tubulin beta- 6 & AT5G12250 & 0 & $82 \%$ \\
\hline$e I F-4 \alpha$ & MN905727 & $\begin{array}{l}\text { Eukaryotic translation initiation } \\
\text { factor } 4 \alpha-1\end{array}$ & AT3G13920 & 0 & $81 \%$ \\
\hline$P P 2 A-1$ & MN905728 & Protein phosphatase 2A-1 & AT1G59830 & $2 \times 10^{-31}$ & $82 \%$ \\
\hline UBC9 & MN905729 & Ubiquitin-conjugating enzyme 9 & AT4G2796 & $6 \times 10^{-60}$ & $81 \%$ \\
\hline UBQ10 & MN905730 & polyubiquitin 10 & AT4G05320 & $10^{-164}$ & $80 \%$ \\
\hline PTBP1 & MN905731 & $\begin{array}{l}\text { Polypyrimidine tractbinding } \\
\text { protein }\end{array}$ & AT3G01150 & $7 \times 10^{-18}$ & $80 \%$ \\
\hline TUA & MN905732 & Tubulin alpha-2 & AT1G50010 & 0 & $99 \%$ \\
\hline$A D P$ & MN905733 & ADP-ribosylation factor & AT1G02430 & $10^{-102}$ & $84 \%$ \\
\hline HIS & MN905734 & Histone & AT5G10980 & $2 \times 10^{-52}$ & $81 \%$ \\
\hline$U B Q 7$ & MN905735 & Ubiquitin-like protein RUB2 & AT2G35635 & $3 \times 10^{-33}$ & $79 \%$ \\
\hline ACT12 & MN905736 & $\begin{array}{l}\text { Actin protein coding } 12 \\
\text { Target gene }\end{array}$ & AT3G46520 & $10^{-124}$ & $80 \%$ \\
\hline$C A T$ & MN905737 & catalase & AT4G21120 & 0.14 & $85 \%$ \\
\hline
\end{tabular}


Table 2. Primers, amplicon characteristics and qRT-PCR parameters for candidate reference genes and target gene.

\begin{tabular}{|c|c|c|c|c|c|c|}
\hline Gene Symbol & Primer Sequence $\left(5^{\prime}-3^{\prime}\right)$ Forward/Reverse & $\begin{array}{l}\text { Amplicon Length } \\
\text { (bp) }\end{array}$ & $\mathbf{R} 2$ & $\begin{array}{c}\text { PCR } \\
\text { Efficiency }(\%)\end{array}$ & SD & $\mathrm{CV}$ \\
\hline GAPDH & ATTGGAAGACTCGTCGCTCG/ACCGAAAACAGCCACAGGTT & 201 & 0.9949 & 104.13 & 1.10 & 5.11 \\
\hline $18 S$ & CAGCGCCATCAAGGAGGAAT/ACCATGCGAGGATCCAACC & 209 & 0.9997 & 103.43 & 0.92 & 3.18 \\
\hline ACT2 & TGAGCTACGAGTTGCTCCAG/GGCGACATACATTGCAGGTG & 130 & 0.9982 & 100.53 & 0.64 & 2.56 \\
\hline TIP41 & ATGCCCGTCAAGAATGGGAG/TCAACGGGTGGTAAGGCTTC & 166 & 0.9922 & 99.79 & 0.83 & 3.06 \\
\hline$E F-1 a$ & TGTGTTGGACTGCCACACTT/TGGGTTTGGAGGGCATCATC & 152 & 0.9972 & 103.43 & 1.40 & 6.12 \\
\hline TUB & TGGTACCATGGATAGCGTGC/TGCCCCTTAGCCCAATTGTT & 105 & 0.9924 & 100.07 & 1.23 & 4.36 \\
\hline$e I F-4 \alpha$ & GCTCTTTGCAAGCTATGATG/CACATCAAGACCCTTGCAGA & 151 & 0.9958 & 99.93 & 1.40 & 6.12 \\
\hline$P P 2 A-1$ & GGAGACATCCATGGGCAGTT/ACGACACGGTCTCAACAGG & 130 & 0.9933 & 99.98 & 0.66 & 2.47 \\
\hline UBC9 & TCCCTATGCAGGGGGTGTAT/GGATCCGTCAACAAGGAGCA & 210 & 0.9918 & 98.35 & 1.15 & 4.95 \\
\hline UBQ10 & GATGGACGTACTCTCGCTGA/AAAATCGCCACCACGAAGAC & 81 & 0.9992 & 99.29 & 1.04 & 4.55 \\
\hline PTВP1 & CCCGTCGAAGGTTTTGCATC/AGCCTGGTTATGGTTGGCTC & 130 & 0.9994 & 101.12 & 0.71 & 2.78 \\
\hline TUA & ATAAGACAGTTGGCGGTGGG/TGCTCTGGGTGAAAGAGCTG & 157 & 0.9992 & 105.62 & 1.23 & 4.98 \\
\hline$A D P$ & ACCAAGCTCTTTCAGCGTCT/GGTCGTCTTACCAGCAGCAT & 81 & 0.9957 & 108.72 & 1.33 & 5.94 \\
\hline HIS & CGAGGCTTACCTTGTAGGGC/CCCTTTCACCGCGAATCCTT & 116 & 0.9978 & 99.5 & 1.06 & 4.77 \\
\hline$U B Q 7$ & CTCCTGTGCAACAGAGGCTT/TAATGACCACCACGTAGGGC & 124 & 0.9978 & 99.66 & 0.86 & 3.54 \\
\hline ACT12 & $\begin{array}{c}\text { CTTGCCGGTCGGGATTTAAC/TTCCAGGGAGGAACTGGTCT } \\
\text { Target gene }\end{array}$ & 174 & 0.9963 & 96.85 & 0.89 & 3.70 \\
\hline CAT & TGCTCACCGTGCTGCATCTA/GCGGCATTGAACACCCCATT & 148 & 0.9918 & 100.38 & & \\
\hline
\end{tabular}




\subsection{Reverse Transcription Quantitative PCR (qRT-PCR) Analysis}

Quantitative RT-PCR reactions were conducted in 96-well plates with a qTOWER 3G Cycler and qPCR software (Analytik Jena, Jena Germany) using the TransStart Top Green qPCR SuperMix (TransGen Biotech, Beijing, China). The $20 \mu \mathrm{L}$ reaction mix contained $10 \mu \mathrm{L}$ TransStart Top Green qPCR SuperMix, $7 \mu \mathrm{L}$ nuclease-free water, $1 \mu \mathrm{L}$ diluted cDNA, and $1 \mu \mathrm{L}$ of each specific primer (final concentration $10 \mu \mathrm{M}$ ). PCR conditions were $94{ }^{\circ} \mathrm{C}$ for $30 \mathrm{~s}$, followed by 45 cycles of $95^{\circ} \mathrm{C}$ for $5 \mathrm{~s}, 59^{\circ} \mathrm{C}$ for $15 \mathrm{~s}$, and $72{ }^{\circ} \mathrm{C}$ for $10 \mathrm{~s}$. Three technical replicates were performed for each sample to ensure the accuracy of the results. All primers used in the study are listed in Table 2.

\subsection{Gene Expression Stability Analysis}

Three different Microsoft Excel-based software programs, geNorm [3], NormFinder [15], and BestKeeper [13,34], were used to analyze the expression stability of the candidate RGs under different experimental conditions. The Cq (PCR cycle threshold) data were used directly in the BestKeeper program, but for geNorm and NormFinder, Cq values were converted into relative values and imported into geNorm and NormFinder program analyzed as described previously [13]. The output of each software program permitted us to rank the expression stability of RGs in different treatment groups. A comprehensive ranking of RGs was also generated as described previously $[35,36]$.

\subsection{Validation of RGs by $q R T-P C R$}

QRT-PCR was also performed to analyze the expression levels of the target gene CAT under different experimental conditions. The top two best RGs and worst ranked RG for each experimental condition were selected normalization of CAT expression in L. olgensis. The quantitative variation between replicates was calculated with the relative quantification method $\left(2^{-\Delta \Delta C T}\right)$ [37]. Graphs were generated using Excel and GraphPad Prism7. The primer for CAT is listed in Table 2.

\section{Results}

\subsection{Selection of Candidate Reference Genes}

Based on sequence homology with Arabidopsis genes, 16 candidate RGs were identified from the L. olgensis transcriptome (unpublished) (Table 1). Subsequently, primer specificity was confirmed based on agarose gel electrophoresis. Amplicons of a single band with the expected size indicate good primer specificity (Figure S1). In qRT-PCR reactions, melting curve analysis of every candidate RG showed a single peak. Amplification efficiency (E) and correlation coefficient values $\left(R^{2}\right)$ of the $R G$ standard curves varied from 96.85 to $108.72 \%$ and from 0.9918 to 0.9997 , respectively (Table 2 and Figure S2).

\subsection{Expression Profiles of Candidate RGs}

The distribution of raw Cq values for the 16 candidate RGs in 20 L. olgensis samples (five samples from each stress condition) is shown in Figure 1. The RGs exhibited a relatively wide range of $\mathrm{Cq}$ values, from $13.07(A D P)$ to 31.75 (18S). The mean Cq values of the RGs varied from 21.63 to 28.85, their SDs varied from 0.64 to 1.4 , and their coefficients of variation (CVs) varied from $2.47 \%$ to $6.12 \%$. As Cq values are negatively related to gene expression levels, the highest maximum expression level was detected in $A D P$, whereas the lowest minimum level was detected in $18 S$ (Figure 2). ADP exhibited the highest variation in expression, and PTBP1 exhibited the lowest variation, with Cq values ranging from 24.20 to 27.62 . eIF- $4 \alpha$ showed relatively moderate variation, with $\mathrm{Cq}$ values ranging from 22.27 to 26.72. A small CV of the $\mathrm{Cq}$ values indicates that a given gene is more stably expressed. The lowest and highest $\mathrm{CV}$ values under the four treatments were GAPHH (0.79\%) and $A D P(15.3 \%)$ under drought stress, $P P 2 A-1(0.65 \%)$ and $A D P(14.06 \%)$ under salt stress, $P P 2 A-1(1.51 \%)$ and $A D P(14.77 \%)$ under cold stress, and $U B Q 7(1.22 \%)$ and $A D P(15.22 \%)$ under heat stress. The ranking of gene stability by 
average $C V$ values across all treatments was $P P 2 A-1>A C T 2>P T B P 1>T I P 41>18 S>U B Q 7>A C T 12$ $>$ IF- $4 \alpha>$ TUB $>U B Q 10>$ HIS $>$ UBC9 $>$ TUA $>$ GADPH $>A D P>E F-1 \alpha$ (Table 2).

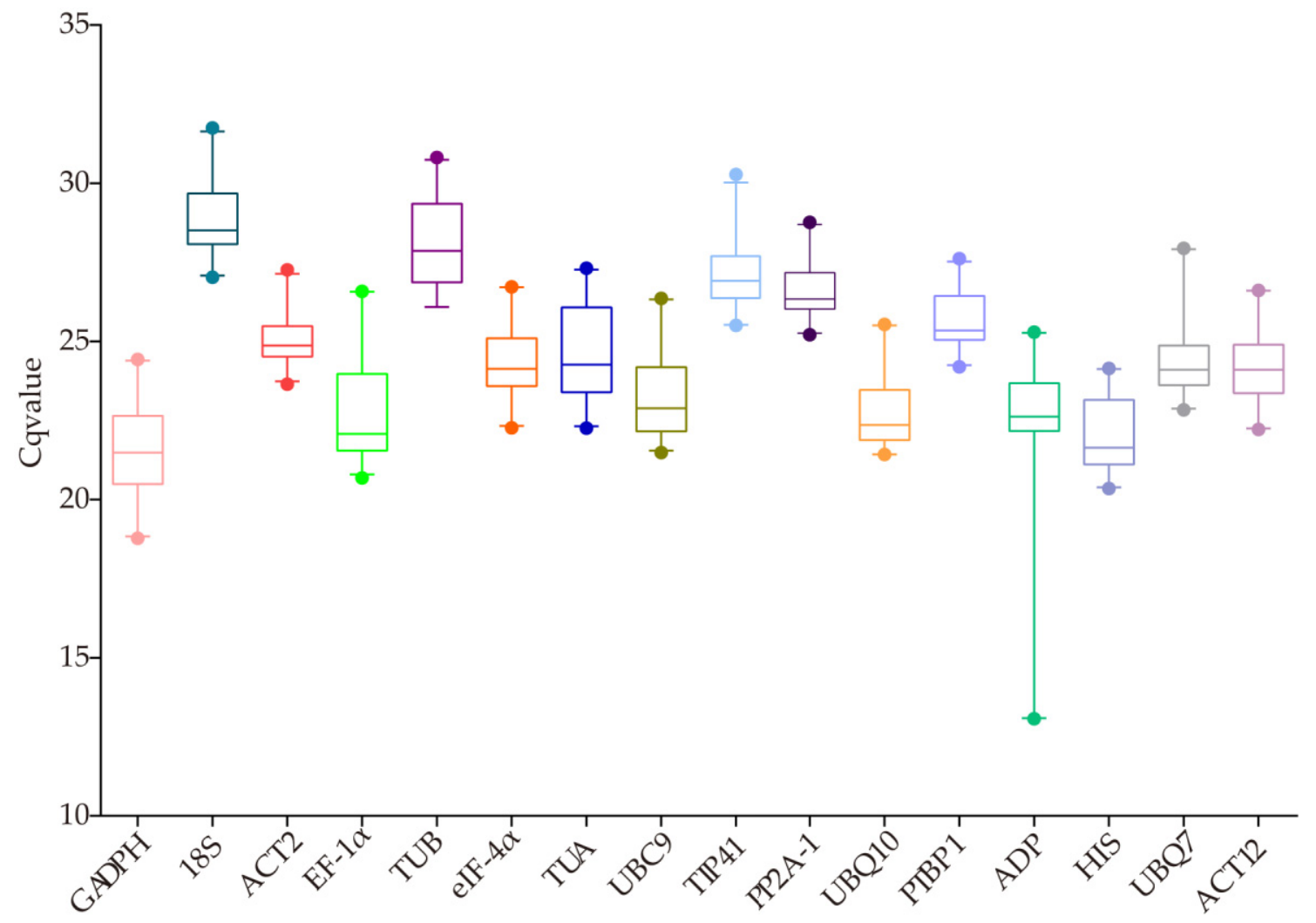

Figure 1. Distribution of raw Cq values for the 16 candidate reference genes (RGs) across all Larix olgensis samples. The lines inside each box represent the medians. The outside box is determined from 25 th to 97.5 th percentiles. The top and bottom whiskers represent the highest and lowest Cq values, respectively.

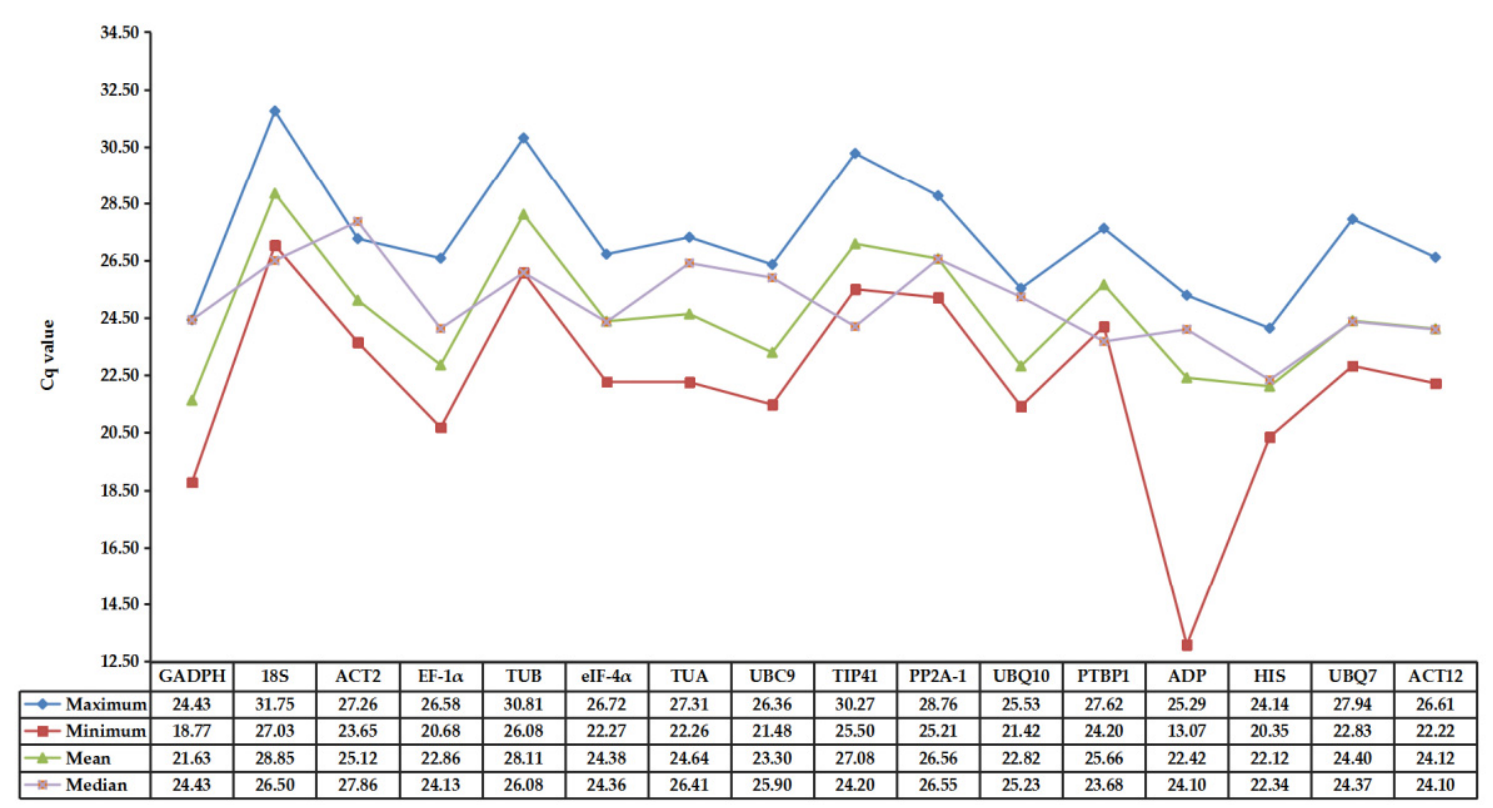

Figure 2. Maximum, minimum, mean, and median Cq values of the 16 candidate reference genes across all samples. 


\subsection{Analysis of Gene Expression Stability}

The software programs geNorm, NormFinder, and BestKeeper were used to analyze the expression stability of the 16 candidate RGs in L. olgensis plants that had been subjected to four experimental treatments. Data from each treatment were analyzed separately and in combination.

geNorm analysis: for geNorm analysis, the $M$-value of candidate RGs was calculated and used to rank RG stability. A gene with an $M$-value below 1.5 is considered to be stably expressed, and the smaller the $M$-value, the more stable the gene [3]. In our study, the $M$-values of all candidate RGs were lower than 1.5 in individual treatments and when the treatments were combined, with the exception of $A D P$ under heat stress. The most suitable RG differed among treatments. As shown in Table 3 and Figure S3, GAPDH and $18 S$ under drought stress, $U B Q 10$ and $P P 2 A-1$ under salt stress, $P P 2 A-1$ and GAPDH under cold stress, and TIP41 and ACT2 under heat stress were ranked as the most stable genes with the lowest $M$-values. $P P 2 A-1$ and $A C T 2$ had the most stable expression when data from all samples were combined, whereas, $A D P$ was the least stable gene in all treatment conditions.

Table 3. Expression stability of candidate reference genes calculated by geNorm.

\begin{tabular}{|c|c|c|c|c|c|c|c|c|c|c|}
\hline \multirow{2}{*}{ Rank } & \multicolumn{2}{|c|}{ Drought } & \multicolumn{2}{|c|}{ Salt } & \multicolumn{2}{|c|}{ Cold } & \multicolumn{2}{|c|}{ Heat } & \multicolumn{2}{|c|}{ Total } \\
\hline & Gene & Stability & Gene & Stability & Gene & Stability & Gene & Stability & Gene & Stability \\
\hline 1 & GAPDH & 0.25 & $P P 2 A-1$ & 0.14 & $P P 2 A-1$ & 0.20 & TIP41 & 0.48 & $P P 2 A-1$ & 0.47 \\
\hline 2 & $18 S$ & 0.25 & UBQ10 & 0.14 & GAPDH & 0.20 & ACT2 & 0.48 & ACT2 & 0.47 \\
\hline 3 & $P P 2 A-1$ & 0.31 & UBC9 & 0.27 & TIP41 & 0.22 & PTBP1 & 0.51 & TIP41 & 0.53 \\
\hline 4 & UBQ10 & 0.35 & $18 S$ & 0.29 & РТВP1 & 0.24 & $e I F-4 \alpha$ & 0.66 & PTBP1 & 0.57 \\
\hline 5 & UBC9 & 0.39 & TIP41 & 0.31 & $18 S$ & 0.26 & $18 S$ & 0.73 & $18 S$ & 0.61 \\
\hline 6 & TIP41 & 0.41 & $e I F-4 \alpha$ & 0.34 & ACT2 & 0.28 & HIS & 0.79 & $e I F-4 \alpha$ & 0.63 \\
\hline 7 & $E F-1 \alpha$ & 0.42 & $E F-1 \alpha$ & 0.37 & $U B Q 10$ & 0.29 & UBC9 & 0.86 & UBC9 & 0.67 \\
\hline 8 & $e I F-4 \alpha$ & 0.45 & TUB & 0.40 & ACT12 & 0.33 & UBQ10 & 0.92 & UBQ10 & 0.71 \\
\hline 9 & ACT12 & 0.48 & PTBP1 & 0.42 & $e I F-4 \alpha$ & 0.36 & TUB & 0.96 & GAPDH & 0.73 \\
\hline 10 & ACT2 & 0.50 & ACT2 & 0.45 & UВС9 & 0.40 & $P P 2 A-1$ & 1.03 & HIS & 0.75 \\
\hline 11 & PTBP1 & 0.53 & GAPDH & 0.47 & $E F-1 \alpha$ & 0.45 & $U B Q 7$ & 1.07 & ACT12 & 0.77 \\
\hline 12 & TUB & 0.56 & $U B Q 7$ & 0.50 & $U B Q 7$ & 0.51 & GAPDH & 1.12 & $U B Q 7$ & 0.80 \\
\hline 13 & TUA & 0.61 & ACT12 & 0.53 & $H \widetilde{H S}$ & 0.55 & TUA & 1.17 & $T \widetilde{U A}$ & 0.84 \\
\hline 14 & HIS & 0.67 & TUA & 0.59 & TUA & 0.66 & ACT12 & 1.22 & $E F-1 \alpha$ & 0.88 \\
\hline 15 & $U B Q 7$ & 0.72 & HIS & 0.66 & TUB & 0.75 & $E F-1 \alpha$ & 1.28 & TUВ & 0.93 \\
\hline 16 & $A D P$ & 1.11 & $A D P$ & 1.06 & $A D P$ & 1.15 & $A D P$ & 1.64 & $A D P$ & 1.10 \\
\hline
\end{tabular}

For qRT-PCR, the selection of a greater number of RGs can permit more accurate quantification of target gene expression. geNorm was used to calculate the pairwise variation $(\mathrm{Vn} / \mathrm{n}+1)$, which permits the determination of an optimal number of RGs for each treatment group using a threshold value of 0.15. There is no need for additional RGs if the variation value is below 0.15 [3]. As shown in Figure 3, the pairwise variation values $\mathrm{V}_{2} / \mathrm{V}_{3}$ for drought, salt, and cold stress samples were all less than 0.15 , indicating that two suitable RGs were adequate for the normalization of data from these treatments. For the heat stress samples, V4/5 was 0.1498 , indicating that four RGs (TIP41, ACT2, PTBP1, and eIF-4 $\alpha$ ) were required. When all samples were combined, V3/4 was 0.1315 , indicating that three RGs (ACT2, $P P 2 A-1$, and TIP41) were required.

NormFinder analysis: the NormFinder approach provides a stability value for each gene based on inter- and intra-group variation in expression [15]. As shown in Table 4, the stability ranks calculated in NormFinder were consistent with those calculated in geNorm under cold stress (GAPDH). The top three most stable genes were GAPDH, 18S, and PP2A-1 under drought stress; ACT2, 18S, UBC9, PPA2-1, and UBQ10 under salt stress; and 18S, PTBP1, and ACT2 under heat stress. These rankings were broadly similar to those of geNorm, although there were some differences. For instance, in the stability rankings for the combined samples, NormFinder suggested that $18 S$ and UBC9 were the two most suitable two RGs, a result that differed from that of geNorm. Similar to geNorm, NormFinder indicated that $A D P$ was the least stable gene in all treatments. Although there were some differences in 
rankings between geNorm and NormFinder, the top five most stable genes were relatively consistent between them.

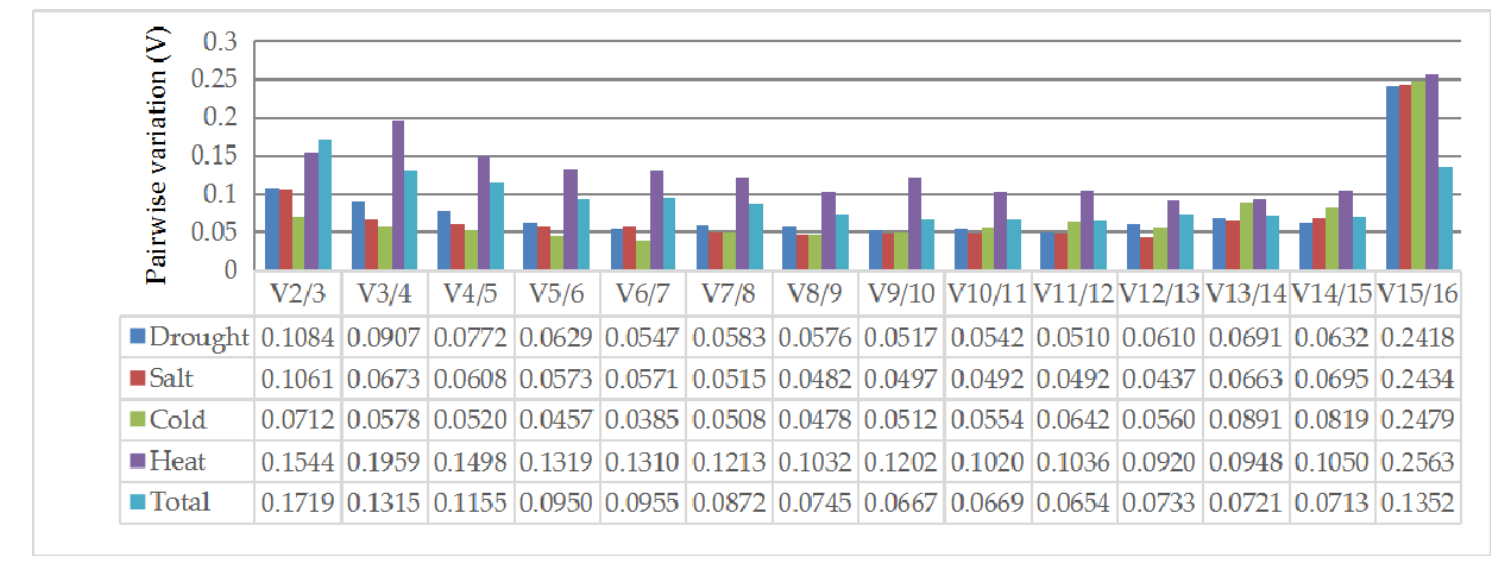

Figure 3. Pairwise variation $(\mathrm{Vn} / \mathrm{Vn}+1)$ values calculated by geNorm for samples from drought, salt, cold, and heat stress, and for the combination of all samples. The threshold value to determine the optimal number of RGs for qRT-PCR normalization is 0.15 .

Table 4. Gene expression stability in L. olgensis. under multiple stress treatments, as ranked by the software program NormFinder.

\begin{tabular}{|c|c|c|c|c|c|c|c|c|c|c|}
\hline \multirow{2}{*}{ Rank } & \multicolumn{2}{|c|}{ Drought } & \multicolumn{2}{|c|}{ Salt } & \multicolumn{2}{|c|}{ Cold } & \multicolumn{2}{|c|}{ Heat } & \multicolumn{2}{|c|}{ Total } \\
\hline & Gene & Stability & Gene & Stability & Gene & Stability & Gene & Stability & Gene & Stability \\
\hline 1 & $P P 2 A-1$ & 0.08 & ACT2 & 0.06 & GAPDH & 0.07 & $18 S$ & 0.20 & $18 S$ & 0.15 \\
\hline 2 & $18 S$ & 0.09 & $18 S$ & 0.07 & $18 S$ & 0.10 & РТВP1 & 0.24 & UBC9 & 0.27 \\
\hline 3 & GAPDH & 0.09 & UBC9 & 0.07 & UBC9 & 0.12 & ACT2 & 0.41 & РТВP1 & 0.28 \\
\hline 4 & $e I F-4 \alpha$ & 0.13 & $P P 2 A-1$ & 0.07 & $P P 2 A-1$ & 0.12 & UBC9 & 0.41 & TIP41 & 0.38 \\
\hline 5 & UBQ10 & 0.17 & UBQ10 & 0.14 & ACT2 & 0.18 & TUB & 0.45 & $e I F-4 \alpha$ & 0.39 \\
\hline 6 & UВС9 & 0.22 & $e I F-4 \alpha$ & 0.15 & UBQ10 & 0.23 & $e I F-4 \alpha$ & 0.48 & UBQ10 & 0.39 \\
\hline 7 & TIP41 & 0.25 & GAPDH & 0.16 & TIP41 & 0.24 & TIP41 & 0.60 & ACT2 & 0.39 \\
\hline 8 & ACT2 & 0.29 & TIP41 & 0.20 & $e I F-4 \alpha$ & 0.25 & UBQ10 & 0.61 & $P P 2 A-1$ & 0.42 \\
\hline 9 & $E F-1 \alpha$ & 0.31 & $E F-1 \alpha$ & 0.28 & РТВP1 & 0.28 & HIS & 0.68 & GAPDH & 0.46 \\
\hline 10 & TUA & 0.41 & TUB & 0.31 & $E F-1 \alpha$ & 0.35 & TUA & 0.68 & HIS & 0.47 \\
\hline 11 & ACT12 & 0.42 & РТВР1 & 0.39 & ACT12 & 0.44 & GAPDH & 0.76 & ACT12 & 0.57 \\
\hline 12 & TUB & 0.43 & ACT12 & 0.48 & $U B Q 7$ & 0.65 & $P P 2 A-1$ & 0.79 & TUA & 0.59 \\
\hline 13 & РТВР1 & 0.44 & $U B Q 7$ & 0.49 & HIS & 0.71 & $U B Q 7$ & 0.95 & $U B Q 7$ & 0.61 \\
\hline 14 & $U B Q 7$ & 0.72 & TUA & 0.55 & TUA & 0.73 & $E F-1 \alpha$ & 1.04 & $E F-1 \alpha$ & 0.66 \\
\hline 15 & HIS & 0.79 & HIS & 0.87 & TUВ & 0.74 & ACT12 & 1.05 & ТUВ & 0.71 \\
\hline 16 & $A D P$ & 2.68 & $A D P$ & 2.70 & $A D P$ & 2.75 & $A D P$ & 2.84 & $A D P$ & 1.50 \\
\hline
\end{tabular}

BestKeeper analysis: another method for detection of suitable RGs is BestKeeper. Unlike the other two programs, BestKeeper ranks RGs based on the standard deviation (SD) and coefficient of variation $(\mathrm{CV})$ of the $\mathrm{Cq}$ values from the qRT-PCR assay. The smaller the $\mathrm{CV}$, the better the stability of the gene was $[13,34]$. The results of BestKeeper analysis are also listed in Table 5. PPA2-1 was ranked first under salt stress and cold stress, with $\mathrm{CV} \pm \mathrm{SD}$ values of $0.17 \pm 0.65$ and $0.40 \pm 1.51$, respectively. GAPDH was ranked first under drought stress, with a $\mathrm{CV} \pm \mathrm{SD}$ of $0.17 \pm 0.79$ and $U B Q 7$ was ranked first under heat stress, with a $C V \pm \mathrm{SD}$ of $0.29 \pm 1.22$. BestKeeper suggested that ACT2 was the most suitable RG when data from all samples were combined. Few genes had an SD greater than 1.0, indicating that most of the candidate RGs were relatively stable. Similar to the results of geNorm and NormFinder, $A D P$ was the least stable RG for all sample sets, with the exception of the combined samples, in which $E F-1 \alpha$ was the least stable. 
Table 5. Gene expression stability in L. olgensis. under multiple stress treatments, as ranked by the software program BestKeepers.

\begin{tabular}{|c|c|c|c|c|c|c|c|c|c|c|c|c|c|c|c|}
\hline \multirow{2}{*}{ Rank } & \multicolumn{3}{|c|}{ Drought } & \multicolumn{3}{|c|}{ Salt } & \multicolumn{3}{|c|}{ Cold } & \multicolumn{3}{|c|}{ Heat } & \multicolumn{3}{|c|}{ Total } \\
\hline & Gene & SD & $\mathrm{CV}$ & Gene & SD & $\mathrm{CV}$ & Gene & SD & $\mathrm{CV}$ & Gene & SD & $\mathrm{CV}$ & Gene & SD & $\mathrm{CV}$ \\
\hline 1 & GADPH & 0.17 & 0.79 & $P P 2 A-1$ & 0.17 & 0.65 & $P P 2 A-1$ & 0.40 & 1.51 & $U B Q 7$ & 0.29 & 1.22 & ACT2 & 0.54 & 2.17 \\
\hline 2 & РТВР1 & 0.63 & 2.43 & UBQ10 & 0.19 & 0.84 & ACT12 & 0.42 & 1.74 & TIP41 & 0.43 & 1.60 & $P P 2 A-1$ & 0.58 & 2.18 \\
\hline 3 & HIS & 0.66 & 2.90 & РТВP1 & 0.23 & 0.93 & РТВP1 & 0.44 & 1.72 & ACT2 & 0.60 & 2.42 & РТВP1 & 0.67 & 2.60 \\
\hline 4 & ACT2 & 0.69 & 2.74 & TIP41 & 0.23 & 0.88 & ACT2 & 0.46 & 1.84 & $P P 2 A-1$ & 0.66 & 2.52 & TIP41 & 0.77 & 2.84 \\
\hline 5 & ACT12 & 0.85 & 3.43 & ACT12 & 0.30 & 1.24 & TIP41 & 0.47 & 1.73 & РТВР1 & 0.81 & 3.14 & $U B Q 7$ & 0.79 & 3.23 \\
\hline 6 & TUB & 0.87 & 3.12 & UBC9 & 0.35 & 1.54 & $18 S$ & 0.53 & 1.88 & GAPDH & 0.93 & 4.51 & ACT12 & 0.85 & 3.54 \\
\hline 7 & $P P 2 A-1$ & 0.88 & 3.26 & $18 S$ & 0.36 & 1.29 & $e I F-4 \alpha$ & 0.54 & 2.23 & $e I F-4 \alpha$ & 0.99 & 4.13 & GAPDH & 0.86 & 4.02 \\
\hline 8 & UBQ10 & 0.90 & 3.91 & $U B Q 7$ & 0.36 & 1.52 & UBQ10 & 0.56 & 2.49 & ACT12 & 1.05 & 4.43 & $18 S$ & 0.90 & 3.11 \\
\hline 9 & $18 S$ & 1.09 & 3.74 & $E F-1 \alpha$ & 0.42 & 1.90 & GAPDH & 0.60 & 2.89 & HIS & 1.06 & 4.73 & $e I F-4 \alpha$ & 0.90 & 3.70 \\
\hline 10 & $U B Q 7$ & 1.13 & 4.46 & $e I F-4 \alpha$ & 0.42 & 1.77 & UBQ7 & 0.76 & 3.11 & TUA & 1.14 & 4.65 & HIS & 1.02 & 4.59 \\
\hline 11 & $E F-1 \alpha$ & 1.15 & 4.96 & TUB & 0.52 & 1.93 & HIS & 0.76 & 3.40 & TUB & 1.19 & 4.14 & UBQ10 & 1.02 & 4.48 \\
\hline 12 & $e I F-4 \alpha$ & 1.16 & 4.60 & ACT2 & 0.53 & 2.14 & UBC9 & 0.94 & 4.09 & $18 \mathrm{~S}$ & 1.32 & 4.59 & UВС9 & 1.15 & 4.94 \\
\hline 13 & TIP41 & 1.18 & 4.24 & HIS & 0.57 & 2.67 & $E F-1 \alpha$ & 0.95 & 4.24 & UВC9 & 1.55 & 6.67 & TUB & 1.20 & 4.25 \\
\hline 14 & UBC9 & 1.20 & 5.06 & GAPDH & 0.60 & 2.84 & TUA & 1.07 & 4.48 & UBQ10 & 1.73 & 7.48 & TUA & 1.22 & 4.93 \\
\hline 15 & TUA & 1.39 & 5.56 & TUA & 0.87 & 3.67 & ТUВ & 1.65 & 5.86 & $E F-1 \alpha$ & 2.15 & 9.18 & $A D P$ & 1.26 & 5.62 \\
\hline 16 & $A D P$ & 3.28 & 15.30 & $A D P$ & 2.87 & 14.06 & $A D P$ & 3.10 & 14.77 & $A D P$ & 3.25 & 15.22 & $E F-1 \alpha$ & 1.39 & 6.07 \\
\hline
\end{tabular}

\subsection{Comprehensive Analysis}

To reduce the effect of any limitations and biases associated with individual algorithms, a comprehensive stability analysis was performed by taking the geometric mean of the geNorm, NormFinder, and BestKeeper rankings in order to identify the best RGs [38]. For comprehensive analysis, two RGs were selected for further normalization. As shown in Table 6 and Figure 4, PP2A-1 was ranked among of the top two most stable RGs under drought, salt, and cold stress, and GAPDH under cold stress, UBQ10 under salt stress were also the most stable RGs, respectively. TIP41 and ACT2 were the most stable RGs under heat stress, and ACT2 and PP2A-1 were the most stable RGs when all samples were combined. The comprehensive RG rankings for single treatments (drought, salt, and cold) and for combined samples were consistent with the results obtained by geNorm and BestKeeper. $A D P$ was the least stable RG under all experimental conditions (Table S1).

Table 6. Gene expression stability ranked by the comprehensive ranking method in L. olgensis.

\begin{tabular}{|c|c|c|c|c|c|c|c|c|c|c|}
\hline \multirow{2}{*}{ Rank } & \multicolumn{2}{|l|}{ Drought } & \multicolumn{2}{|l|}{ Salt } & \multicolumn{2}{|l|}{ Cold } & \multicolumn{2}{|l|}{ Heat } & \multicolumn{2}{|l|}{ Total } \\
\hline & Gene & Stability & Gene & Stability & Gene & Stability & Gene & Stability & Gene & Stability \\
\hline 1 & GAPDH & 1.44 & $P P 2 A-1$ & 2.00 & $P P 2 A-1$ & 1.59 & TIP41 & 2.41 & ACT2 & 2.41 \\
\hline 2 & $P P 2 A-1$ & 2.76 & UBQ10 & 2.15 & GAPDH & 2.62 & ACT2 & 2.62 & $P P 2 A-1$ & 2.52 \\
\hline 3 & $18 S$ & 3.30 & $\widetilde{U B C 9}$ & 3.78 & $18 S$ & 3.91 & РТВP1 & 3.11 & РТВР1 & 3.30 \\
\hline 4 & $U B Q 10$ & 5.43 & $18 S$ & 3.83 & TIP41 & 4.72 & $18 S$ & 3.91 & $18 S$ & 3.42 \\
\hline 5 & РТВP1 & 6.59 & ACT2 & 4.93 & РТВР1 & 4.76 & $U B Q 7$ & 5.23 & TIP41 & 3.63 \\
\hline 6 & ACT2 & 6.84 & TIP41 & 5.43 & ACT2 & 4.93 & $e I F-4 \alpha$ & 5.52 & UBC9 & 5.52 \\
\hline 7 & $e I F-4 \alpha$ & 7.27 & РТВP1 & 6.67 & ACT12 & 5.60 & UВC9 & 7.14 & $e I F-4 \alpha$ & 6.46 \\
\hline 8 & UBC9 & 7.49 & $e I F-4 \alpha$ & 7.11 & UBQ10 & 6.95 & $P P 2 A-1$ & 7.83 & UBQ10 & 8.08 \\
\hline 9 & ACT12 & 7.91 & $E F-1 \alpha$ & 8.28 & UВC9 & 7.11 & HIS & 7.86 & GAPDH & 8.28 \\
\hline 10 & ТIP41 & 8.17 & ACT12 & 9.21 & $e I F-4 \alpha$ & 7.96 & TUB & 7.91 & ACT12 & 8.99 \\
\hline 11 & HIS & 8.57 & TUB & 9.58 & $E F-1 \alpha$ & 11.27 & GAPDH & 9.25 & $U B Q 7$ & 9.21 \\
\hline 12 & $E F-1 \alpha$ & 8.85 & GAPDH & 10.25 & $U B Q 7$ & 11.29 & UBQ10 & 9.64 & HIS & 10.00 \\
\hline 13 & TUB & 9.52 & UBQ7 & 10.77 & HIS & 12.30 & TUA & 10.91 & TUA & 12.97 \\
\hline 14 & TUA & 12.49 & HIS & 14.30 & TUA & 14.00 & ACT12 & 11.89 & TUB & 14.30 \\
\hline 15 & $U B Q 7$ & 12.81 & TUA & 14.33 & ТUВ & 15.00 & $E F-1 \alpha$ & 14.66 & $E F-1 \alpha$ & 14.64 \\
\hline 16 & $A D P$ & 16.00 & $A D P$ & 16.00 & $A D P$ & 16.00 & $A D P$ & 16.00 & $A D P$ & 15.66 \\
\hline
\end{tabular}




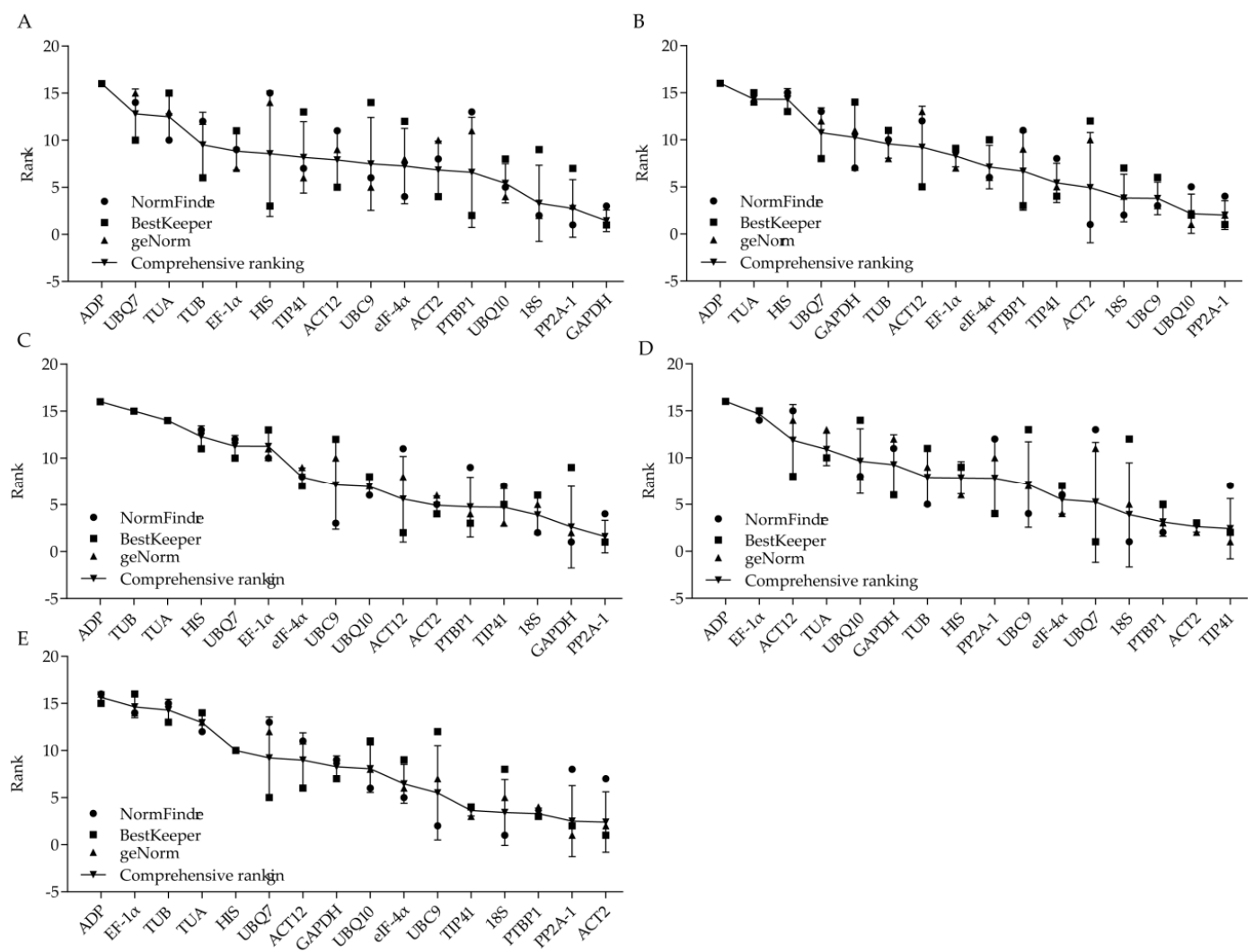

Figure 4. Comprehensive ranking of the 16 RGs in L. olgensis calculated as the geometric mean of three types of ranking (geNorm, NormFinder, and BestKeeper) for each sample group. (A) Drought stress. (B) Salt stress. (C) Cold stress. (D) Heat stress. (E) All samples.

\subsection{Validation of CAT Reference Gene}

To verify the reliability of the selected reference genes, CAT was selected as a target gene. The expression of the antioxidant $C A T$ gene is induced by many abiotic stresses, including chilling, drought, osmotic stress, and salt stress [39-41]. The CAT sequence was obtained from L. olgensis transcriptome data and showed $48.75 \%$ nucleotide identity with $C A T$ from Arabidopsis. We used the comprehensive ranking results to select the top two stable RGs for normalization of $C A T$ expression in L. olgensis needles. The selected RGs were $P P 2 A-1$ and GAPDH for drought and cold stress, $P P 2 A-1$ and $U B Q 10$ for salt stress, and TIP41 and ACT2 for heat stress. As shown in Figure 5, the expression patterns of $C A T$ showed few differences when different stable RGs were used. Similar expression patterns were obtained under drought and cold stress when GAPDH and PP2A-1 were used for normalization. $C A T$ expression reached a peak at $12 \mathrm{~h}$ for both drought stress ( $<29$-fold) and cold stress ( $<5$-fold). When using the most stable RGs for salt stress $P P 2 A-1$ and $U B Q 10, C A T$ expression patterns were consistent, and the highest expression was observed at $24 \mathrm{~h}$ (no more than 10-fold). Under heat stress, CAT expression levels reached a similar peak at $6 \mathrm{~h}$ when normalized with TIP41 and ACT2. However, large differences in expression patterns were detected when the least stable $R G, A D P$, was used for normalization under the same stresses. Specifically, the expression levels of $C A T$ were overestimated. 
A

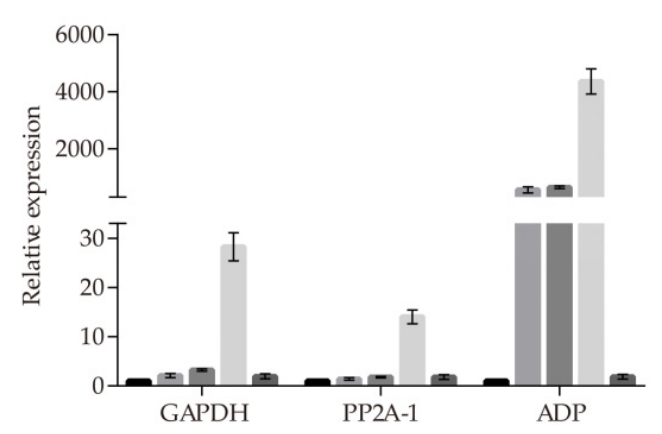

C

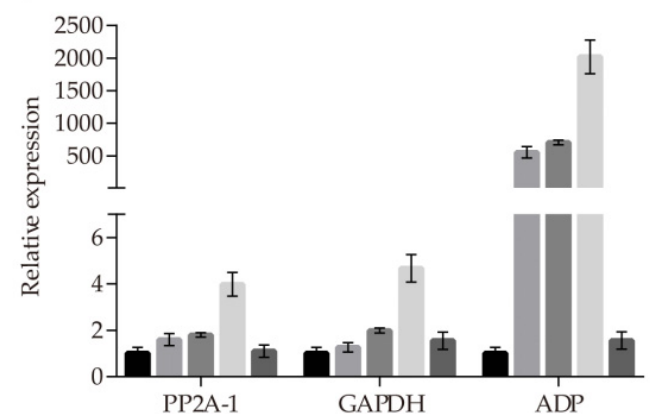

B

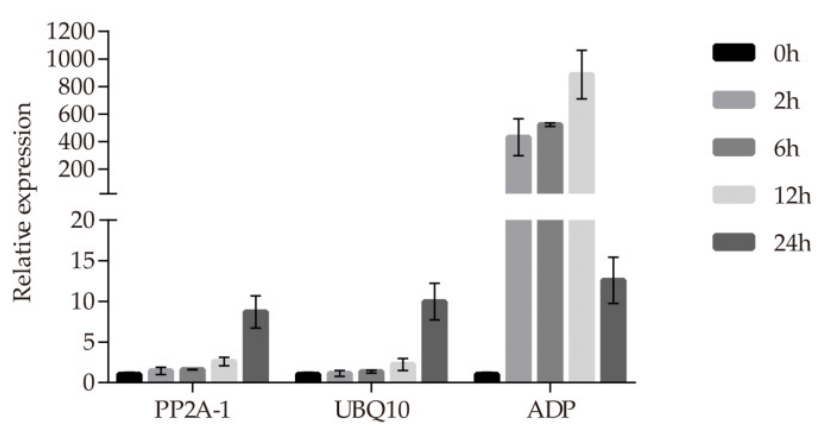

$\mathrm{D}$

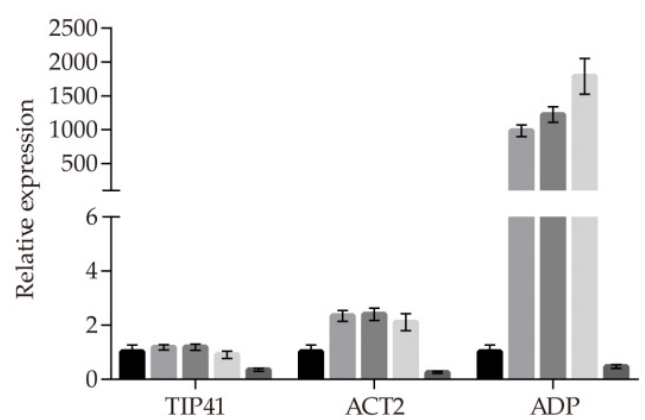

Figure 5. Relative expression of LoCAT gene under abiotic stresses normalized using the top two stable RGs and one unstable RG. (A) Drought stress. (B) Salt stress. (C) Cold stress. (D) Heat stress.

\section{Discussion}

Quantitative RT-PCR is an important technology that permits rapid and reliable quantification of gene expression [41]. Due to its high sensitivity, many experimental variables can easily affect the reliability of qRT-PCR gene expression results [4]. Therefore, to obtain more reliable results, an appropriate normalization strategy is very important. Among several methods [1,2], selection of one or more RGs as normalization factor(s) is the most common approach for different experimental conditions such as abiotic stress $[38,42,43]$. However, no research on RGs for L. olgensis under abiotic stress has been reported. In this study, we identified appropriate L. olgensis RGs under different abiotic stress conditions using qRT-PCR and parallel calculations in geNorm, Normfinder, Bestkeeper, and comprehensive analysis.

Sixteen potential RGs were identified from L. olgensis transcriptome data generated in our laboratory. Three statistical algorithms, geNorm, NormFinder, and BestKeeper, were used to assess the expression stability of candidate RGs for accurate normalization in gene expression studies [20]. In the geNorm analysis, $M$-values of the RGs under different experimental conditions were all less than 1.5 (except $A D P$ in heat stress), indicating their potential expression stability [44]. The candidate RGs exhibited differential stability and relative rankings in response to different stresses. In two treatments, the most stable genes calculated by geNorm and Bestkeeper were consistent, namely GAPDH in drought and $P P 2 A-1$ in cold (Tables 3 and 5). In salt and heat stress, the most stable genes calculated by the three algorithms differed. For heat stress, TIP41 and ACT2 were ranked as the most stable RGs according to the $M$-values calculated in geNorm. NormFinder regarded $18 \mathrm{~S}$ as the most stable RG, and BestKeeper identified $U B Q 7$ as the most stable RG; however, UBQ7 was ranked lower by geNorm and Normfinder (Tables 3 and 4). The differences in ranking were mainly caused by variations in the algorithms of the three programs. Previous work has also shown that the three programs generate different results under abiotic stress in Vitis vinifera [45]. A comprehensive analysis is therefore necessary to provide ultimate stability rankings for RGs under different treatments, as reported previously $[46,47]$. 
Our comprehensive ranking results showed that $P P 2 A-1$ and GAPDH were the top two most stable RGs under drought and cold stress. $P P 2 A-1$ also ranked first under salt stress in the comprehensive analysis. Our findings confirm several previous studies in which $P P 2 A-1$ was also shown to be the most stable RG. These include studies of Pennisetum glaucum under different abiotic stresses and hormonal stimuli [48], Agrostis stolonifera under different abiotic stresses [49], P. euphratica under drought stress [50], and M. charantia under salt stress [51]. GAPDH also ranked as a highly suitable RG under drought and cold stress in this study. This result is in agreement with previous research on Caragana korshinskii under heat stress [46] and Coffea arabica leaves under drought stress and GA, $\mathrm{SA}$, and MeJA treatments [52]. However, GAPDH was ranked as the least stable RG in various tissues and under abiotic stresses in Sorghum bicolor and in various tissues and under PEG6000 and MeJA treatments in Peucedanum praeruptorum [53,54]. These results demonstrate that there is no universal RG that is stably expressed in all treatments and tissues.

$U B Q 10$ was also the most stable RG pair with PP2A-1 under salt stress. UBQ10 was also the most constitutively expressed polyubiquitin gene in A. thaliana across all development processes [44], in Prunus persica fruit at multiple developmental stages [55] and in Platycladus orientalis under $\mathrm{NaCl}$ and ABA treatments [56]. However, in O. sativa, UBQ10 was the least stable RG in different tissues, cell types, and developmental stages, a result similar to that observed in Glycine max [57]. In the present study, TIP41 and ACT2 showed highly stable expression under heat stress. In a previous work, TIP41 was a stable RG in M. charantia under $\mathrm{UV}$ and $\mathrm{CuSO}_{4}$ treatments [51] and in P. praeruptorum under $\mathrm{NaCl}$ stress [54]. No previous research has shown that TIP41 is the most stable RG under heat stress. ACT2 is a traditional housekeeping gene widely used in many species, such as Betula platyphylla under salt stress and Panicum virgatum $\mathrm{L}$. leaves and roots $[58,59]$. In this study, ACT2 was an appropriate RG under heat stress, consistent with results from P. praeruptorum under heat stress [54]. Nonetheless, geNorm, NormFinder, and Bestkeeper all showed that $A D P$ was the least stable RG under different experimental conditions. Previous studies have shown that $A D P$ is the most stably RG in many species, such as Triticeae [60], Triticum aestivum L [61], and Swingle citrumelo [62]. However, $A D P$ was recognized as the least stable gene by three algorithms for all samples in this study. Several papers have reported similar results. For example, GAPDH ranked the worst in T. aestivum but showed the most stability in V. vinifera cv. Cabernet Sauvignon [63,64]; UBI and ACT showed instability in $S$. lycopersicum [7], but performed suitably in T. aestivum [63]. These results indicate that the expression stabilities of RGs vary in different tissues and under environmental stresses.

Plant growth and development are generally affected by abiotic stresses (cold, heat, drought, and high salinity), and previous research has shown that $C A T$ is the predominant enzyme controlling $\mathrm{H}_{2} \mathrm{O}_{2}$ levels. CAT has often been used as an abiotic-stress-inducible gene, upregulated by drought [40], cold [65], and salt [66] treatments. CAT1 exhibited increased expression in response to exogenous ABA and osmotic stress in maize [39], and its expression was activated by drought, ABA and salt stress in A. thaliana [67]. In this study, CAT expression was upregulated gradually and reached a maximum value at $24 \mathrm{~h}(\approx 10$-fold upregulated) under salt stress when using the two most stable RGs, PP2A-1 and $U B Q 10$, for normalization. The $C A T$ expression pattern was consistent with previously reported responses of $P g C A T 1$ to salt stress, which showed the highest $P g C A T 1$ expression at $24 \mathrm{~h}[66]$ and the highest transcript levels as 10-fold [14]. However, the expression level of $C A T$ was overestimated when the least stable RG, $A D P$, was used for normalization (Figure 5). Like salt stress, large differences were detected in CAT expression pattern when the least RG rather than the two most stable RGs was used for normalization under drought, cold, and heat stress (Figure 5). These results demonstrate that it is necessary to select a suitable stable RG for normalization of target gene expression under different conditions.

In this study, needles were used as the single material to test RGs in L. olgensis. The identified RGs may not apply to a broad range of developmental tissue samples of L. olgensis. For further studies, we will focus on exploring appropriate reference genes among different tissues and different developmental stages for accurate determination of gene expression in L. olgensis in further related research. 


\section{Conclusions}

We selected 16 candidate RGs to validate suitable RGs using three statistical algorithms (geNorm, NormFinder, BestKeeper, and comprehensive analysis) for gene expression normalization in L. olgensis under drought, salt, cold, and heat stress. The results were compared and ranked using a comprehensive analysis. Based on the comprehensive analysis of gene stability, we identified PP2A-1 and GAPDH as the most stable RGs under drought and cold stresses and PP2A-1 and UBQ10 as the two most stable RGs under salt stress. TIP41 and ACT2 were the most stable RGs under heat stress, and ADP was the least stable RG under all stresses. Furthermore, the expression profiles of CAT confirmed the importance of using two suitable RGs rather than one unstable RG under different stresses. Selection of suitable RGs provides a foundation for functional genomic studies in L. olgensis and other woody plants under abiotic stress conditions.

Supplementary Materials: The following are available online at http://www.mdpi.com/1999-4907/11/2/193/s1, Figure S1: Agarose gel electrophoresis of PCR products for each of the 16 RGs and the one target genes in Larix olgensis., Figure S2: Melting curve for 16 RGs and one target gene CAT in L. olgensis, Figure S3: Average expression stability values ( $M$-values) of the 16 RGs in L. olgensis calculated by geNorm. Table S1: Expression stability ranking of the 16 candidate reference genes under different abiotic stresses in L. olgensis.

Author Contributions: Conceptualization, D.L. and C.L.; experimental design: C.L.; material collection and performing the experiments: D.L., X.L., S.Y., M.Z., and J.Y.; data analysis: D.L. and S.Y.; software, D.L.; writing_original draft: D.L.; writing—review and editing: D.L. and C.L.; All authors approved the final draft. All authors have read and agreed to the published version of the manuscript.

Funding: This work was supported by the Fundamental Research Funds for the Central Universities of China (Grant No. 2572017AA04), the 111 Project (Grant No. B16010), the Genetically Modified Organisms Breeding Major Projects of China (Grant No. 2018ZX08020003), and Heilongjiang Touyan Innovation Team Program (Tree Genetics and Breeding Innovation Team).

Acknowledgments: We thank TopEdit (www.topeditsci.com) for the linguistic assistance during the preparation of this manuscript.

Conflicts of Interest: The authors declare that they have no competing interests.

\section{References}

1. Miao, L.; Qin, X.; Gao, L.; Li, Q.; Li, S.; He, C.; Li, Y.; Yu, X. Selection of reference genes for quantitative real-time PCR analysis in cucumber (Cucumis sativus L.), pumpkin (Cucurbita moschata Duch.) and cucumber-pumpkin grafted plants. Peer] 2019, 7, e6536. [CrossRef] [PubMed]

2. Wong, M.L.; Medrano, J.F. Real-time PCR for mRNA quantitation. Biotechniques 2005, 39, 75-85. [CrossRef] [PubMed]

3. Vandesompele, J.; De Preter, K.; Pattyn, F.; Poppe, B.; Van Roy, N.; De Paepe, A.; Speleman, F. Accurate normalization of real-time quantitative RT-PCR data by geometric averaging of multiple internal control genes. Genome Biol. 2002, 3, 532-538. [CrossRef] [PubMed]

4. Dheda, K.; Huggett, J.F.; Bustin, S.A.; Johnson, M.A.; Rook, G.; Zumla, A. Validation of housekeeping genes for normalizing RNA expression in real-time PCR. Biotechniques 2004, 37, 112-119. [CrossRef] [PubMed]

5. Chan, Z. Expression profiling of ABA pathway transcripts indicates crosstalk between abiotic and biotic stress responses in Arabidopsis. Genomics 2012, 100, 110-115. [CrossRef]

6. Jain, M.; Nijhawan, A.; Tyagi, A.K.; Khurana, J.P. Validation of housekeeping genes as internal control for studying gene expression in rice by quantitative real-time PCR. Biochem. Biophys. Res. Commun. 2006, 345, 646-651. [CrossRef]

7. Mascia, T.; Santovito, E.; Gallitelli, D.; Cillo, F. Evaluation of reference genes for quantitative reverse-transcription polymerase chain reaction normalization in infected tomato plants. Mol. Plant Pathol. 2010, 11, 805-816. [CrossRef]

8. Zhou, Z.; Cong, P.; Tian, Y.; Zhu, Y. Using RNA-seq data to select reference genes for normalizing gene expression in apple roots. PLoS ONE 2017, 12, e185288. [CrossRef]

9. Xu, M.; Zhang, B.; Su, X.; Zhang, S.; Huang, M. Reference gene selection for quantitative real-time polymerase chain reaction in Populus. Anal. Biochem. 2011, 408, 337-339. [CrossRef] 
10. Guenin, S.; Mauriat, M.; Pelloux, J.; Van Wuytswinkel, O.; Bellini, C.; Gutierrez, L. Normalization of qRT-PCR data: the necessity of adopting a systematic, experimental conditions-specific, validation of references. J. Exp. Bot. 2009, 60, 487-493. [CrossRef]

11. Joseph, J.T.; Poolakkalody, N.J.; Shah, J.M. Plant reference genes for development and stress response studies. J. Biosci. 2018, 43, 173-187. [CrossRef] [PubMed]

12. Sgamma, T.; Pape, J.; Massiah, A.; Jackson, S. Selection of reference genes for diurnal and developmental time-course real-time PCR expression analyses in lettuce. Plant Methods 2016, 12, 21. [CrossRef] [PubMed]

13. Li, M.Y.; Song, X.; Wang, F.; Xiong, A.S. Suitable reference genes for accurate gene expression analysis in parsley (Petroselinum crispum) for abiotic stresses and hormone stimuli. Front. Plant Sci. 2016, 7, 1481. [CrossRef] [PubMed]

14. Zhang, Y.; Han, X.; Chen, S.; Zheng, L.; He, X.; Liu, M.; Qiao, G.; Wang, Y.; Zhuo, R. Selection of suitable reference genes for quantitative real-time PCR gene expression analysis in Salix matsudana under different abiotic stresses. Sci. Rep. 2017, 7, 40290. [CrossRef]

15. Andersen, C.L.; Jensen, J.L.; Orntoft, T.F. Normalization of real-time quantitative reverse transcription-PCR data: a model-based variance estimation approach to identify genes suited for normalization, applied to bladder and colon cancer data sets. Cancer Res. 2004, 64, 5245-5250. [CrossRef]

16. Feng, K.; Liu, J.X.; Xing, G.M.; Sun, S.; Li, S.; Duan, A.Q.; Wang, F.; Li, M.Y.; Xu, Z.S.; Xiong, A.S. Selection of appropriate reference genes for RT-qPCR analysis under abiotic stress and hormone treatment in celery. PeerJ 2019, 7, e7925. [CrossRef]

17. Ma, S.; Niu, H.; Liu, C.; Zhang, J.; Hou, C.; Wang, D. Expression stabilities of candidate reference genes for RT-qPCR under different stress conditions in soybean. PLOS ONE 2013, 8, e0075271. [CrossRef]

18. Wan, Q.; Chen, S.; Shan, Z.; Yang, Z.; Chen, L.; Zhang, C.; Yuan, S.; Hao, Q.; Zhang, X.; Qiu, D.; et al. Stability evaluation of reference genes for gene expression analysis by RT-qPCR in soybean under different conditions. PLoS ONE 2017, 12, e0189405. [CrossRef]

19. Migocka, M.; Papierniak, A. Identification of suitable reference genes for studying gene expression in cucumber plants subjected to abiotic stress and growth regulators. Mol. Breed. 2011, 28, 343-357. [CrossRef]

20. Vasyutkina, E.A.; Reunova, G.D.; Tupikin, A.E.; Zhuravlev, Y.N. Mitochondrial DNA variation in Olga Bay larch (Larix olgensis A. Henry) from Primorsky Krai of Russia. Genetika 2014, 50, 291-298. [CrossRef]

21. Zhu, J.; Yang, K.; Yan, Q.; Liu, Z.; Yu, L.; Wang, H. Feasibility of implementing thinning in even-aged Larix olgensis plantations to develop uneven-aged larch-broadleaved mixed forests. J. For. Res. 2010, 15, 71-80. [CrossRef]

22. Shen, C.; Wang, L.; Li, M. The altitudinal variability and temporal instability of the climate-tree-ring growth relationships for Changbai larch (Larix olgensis Henry) in the Changbai mountains area, Jilin, Northeastern China. Trees 2016, 30, 901-912. [CrossRef]

23. Guan, C.; Zhang, H.; Zhang, L.; Li, X.; Deng, J.; Jiang, T. Construction of genetic linkage maps of larch (Larix kaempferi $\times$ Larix gmelini) by rapd markers and mapping of QTLs for larch. Biotechnol. Biotechnol. Equip. 2011, 25, 2197-2202. [CrossRef]

24. Hu, X.; Yang, J.; Li, C. Transcriptomic response to nitric oxide treatment in Larix olgensis Henry. Int. J. Mol. Sci. 2015, 16, 28582-28597. [CrossRef] [PubMed]

25. Han, H.; Sun, X.; Xie, Y.; Feng, J.; Zhang, S. Transcriptome and proteome profiling of adventitious root development in hybrid larch (Lari kaempferi $\times$ Lari olgensis). BMC Plant Biol. 2014, 14, 305 . [CrossRef] [PubMed]

26. Zhao, J.; Xiong, H.; Wang, J.; Zhang, H.; Zhang, L. Mining Myb transcription factors related to wood development in Larix olgensis. J. For. Res. 2019. [CrossRef]

27. Li, D.; Hu, X.; Li, C. Overexpression of the LoMYB29 gene of Larix olgensis contributes to the regulation of proanthocyanidin biosynthesis in Arabidopsis thaliana. J. For. Res. 2019, 30, 1793-1804. [CrossRef]

28. $\mathrm{Hu}, \mathrm{X} . ; \mathrm{Xu}, \mathrm{X}$; Li, C. Ectopic expression of the LoERF017 transcription factor from Larix olgensis Henry enhances salt and osmotic-stress tolerance in Arabidopsis thaliana. Plant Biotechnol. Rep. 2018, 12, 93-104. [CrossRef]

29. Chen, R.; Chen, W.; Tigabu, M.; Zhong, W.; Li, Y.; Ma, X.; Li, M. Screening and evaluation of stable reference genes for quantitative real-time polymerase chain reaction (qRT-PCR) analysis in Chinese fir roots under water, phosphorus, and nitrogen stresses. Forests 2019, 10, 1087. [CrossRef] 
30. Paschalidis, K.; Tsaniklidis, G.; Wang, B.; Delis, C.; Trantas, E.; Loulakakis, K.; Makky, M.; Sarris, P.F.; Ververidis, F.; Liu, J. The interplay among polyamines and nitrogen in plant stress responses. Plants 2019, 8, 315. [CrossRef]

31. Nie, Q.; Gao, G.L.; Fan, Q.J.; Qiao, G.; Wen, X.P.; Liu, T.; Peng, Z.J.; Cai, Y.Q. Isolation and characterization of a catalase gene "HuCAT3" from pitaya (Hylocereus undatus) and its expression under abiotic stress. Gene 2015, 563, 63-71. [CrossRef] [PubMed]

32. Tian, C.; Jiang, Q.; Wang, F.; Wang, G.L.; Xu, Z.S.; Xiong, A.S. Selection of suitable reference genes for qPCR normalization under abiotic stresses and hormone stimuli in carrot leaves. PLoS ONE 2015, 10, e117569. [CrossRef] [PubMed]

33. Jaakola, L.; Pirttila, A.M.; Halonen, M.; Hohtola, A. Isolation of high quality RNA from bilberry (Vaccinium myrtillus L.) fruit. Mol. Biotechnol. 2001, 19, 201-203. [CrossRef]

34. Pfaffl, M.W.; Tichopad, A.; Prgomet, C.; Neuvians, T.P. Determination of stable housekeeping genes, differentially regulated target genes and sample integrity: BestKeeper-Excel-based tool using pair-wise correlations. Biotechnol. Lett. 2004, 26, 509-515. [CrossRef]

35. Li, M.Y.; Wang, F.; Jiang, Q.; Wang, G.L.; Tian, C.; Xiong, A.S. Validation and comparison of reference genes for qPCR normalization of celery (Apium graveolens) at different development stages. Front. Plant Sci. 2016, 7, 313. [CrossRef]

36. Niu, X.; Qi, J.; Chen, M.; Zhang, G.; Tao, A.; Fang, P.; Xu, J.; Onyedinma, S.A.; Su, J. Reference genes selection for transcript normalization in kenaf (Hibiscus cannabinus L.) under salinity and drought stress. PeerJ 2015, 3, e1347. [CrossRef]

37. VanGuilder, H.D.; Vrana, K.E.; Freeman, W.M. Twenty-five years of quantitative PCR for gene expression analysis. Biotechniques 2008, 44, 619-626. [CrossRef]

38. Niu, X.; Qi, J.; Zhang, G.; Xu, J.; Tao, A.; Fang, P.; Su, J. Selection of reliable reference genes for quantitative real-time PCR gene expression analysis in Jute (Corchorus capsularis) under stress treatments. Front. Plant Sci. 2015, 6, 848. [CrossRef]

39. Guan, L.M.; Zhao, J.; Scandalios, J.G. Cis-elements and trans-factors that regulate expression of the maize Cat1 antioxidant gene in response to ABA and osmotic stress: $\mathrm{H}_{2} \mathrm{O}_{2}$ is the likely intermediary signaling molecule for the response. Plant J. 2000, 22, 87-95. [CrossRef]

40. Luna, C.M.; Pastori, G.M.; Driscoll, S.; Groten, K.; Bernard, S.; Foyer, C.H. Drought controls on $\mathrm{H}_{2} \mathrm{O}_{2}$ accumulation, catalase (CAT) activity and CAT gene expression in wheat. J. Exp. Bot. 2005, 56, 417-423. [CrossRef]

41. Du, Y.Y.; Wang, P.C.; Chen, J.; Song, C.P. Comprehensive functional analysis of the catalase gene family in Arabidopsis thaliana. J. Integr. Plant Biol. 2008, 50, 1318-1326. [CrossRef] [PubMed]

42. Bogdanovic, M.D.; Dragicevic, M.B.; Tanic, N.T.; Todorovic, S.I.; Misic, D.M.; Zivkovic, S.T.; Tissier, A.; Simonovic, A.D. Reverse transcription of $18 \mathrm{~S}$ rRNA with poly (dT) (18) and other homopolymers. Plant Mol. Biol. Rep. 2013, 31, 55-63. [CrossRef]

43. Zhu, P.; Ma, Y.; Zhu, L.; Chen, Y.; Li, R.; Ji, K. Selection of suitable reference genes in Pinus massoniana Lamb. under different abiotic stresses for qPCR normalization. Forests 2019, 10, 632. [CrossRef]

44. Czechowski, T.; Stitt, M.; Altmann, T.; Udvardi, M.K.; Scheible, W.R. Genome-wide identification and testing of superior reference genes for transcript normalization in Arabidopsis. Plant Physiol. 2005, 139, 5-17. [CrossRef]

45. Luo, M.; Gao, Z.; Li, H.; Li, Q.; Zhang, C.; Xu, W.; Song, S.; Ma, C.; Wang, S. Selection of reference genes for miRNA qRT-PCR under abiotic stress in grapevine. Sci. Rep. 2018, 8, 4444. [CrossRef] [PubMed]

46. Yang, Q.; Yin, J.; Li, G.; Qi, L.; Yang, F.; Wang, R.; Li, G. Reference gene selection for qRT-PCR in Caragana korshinskii Kom. under different stress conditions. Mol. Biol. Rep. 2014, 41, 2325-2334. [CrossRef] [PubMed]

47. Niu, X.; Chen, M.; Huang, X.; Chen, H.; Tao, A.; Xu, J.; Qi, J. Reference gene selection for qRT-PCR normalization analysis in kenaf (Hibiscus cannabinus L.) under abiotic stress and hormonal stimuli. Front. Plant Sci. 2017, 8, 771. [CrossRef]

48. Saha, P.; Blumwald, E. Assessing reference genes for accurate transcript normalization using quantitative real-time PCR in pearl millet [Pennisetum glaucum (L.) R. Br.]. PLoS ONE 2014, 9, e0106308. [CrossRef]

49. Chen, Y.; Hu, B.; Tan, Z.; Liu, J.; Yang, Z.; Li, Z.; Huang, B. Selection of reference genes for quantitative real-time PCR normalization in creeping bentgrass involved in four abiotic stresses. Plant Cell Rep. 2015, 34, 1825-1834. [CrossRef] 
50. Wang, H.L.; Chen, J.; Tian, Q.; Wang, S.; Xia, X.; Yin, W. Identification and validation of reference genes for Populus euphratica gene expression analysis during abiotic stresses by quantitative real-time PCR. Physiol. Plant 2014, 152, 529-545. [CrossRef]

51. Wang, Z.; Xu, J.; Liu, Y.; Chen, J.; Lin, H.; Huang, Y.; Bian, X.; Zhao, Y. Selection and validation of appropriate reference genes for real-time quantitative PCR analysis in Momordica charantia. Phytochemistry 2019, 164, 1-11. [CrossRef]

52. Barsalobres-Cavallari, C.F.; Severino, F.E.; Maluf, M.P.; Maia, I.G. Identification of suitable internal control genes for expression studies in Coffea arabica under different experimental conditions. BMC Mol. Biol. 2009, 10, 1. [CrossRef] [PubMed]

53. Sudhakar, R.P.; Srinivas, R.D.; Sivasakthi, K.; Bhatnagar-Mathur, P.; Vadez, V.; Sharma, K.K. Evaluation of sorghum [Sorghum bicolor (L.)] reference genes in various tissues and under abiotic stress conditions for quantitative real-time PCR data normalization. Front. Plant Sci. 2016, 7, 529. [CrossRef] [PubMed]

54. Zhao, Y.; Luo, J.; Xu, S.; Wang, W.; Liu, T.; Han, C.; Chen, Y.; Kong, L. Selection of reference genes for gene expression normalization in Peucedanum praeruptorum Dunn under abiotic stresses, hormone treatments and different tissues. PLoS ONE 2016, 11, e152356. [CrossRef] [PubMed]

55. Tong, Z.; Gao, Z.; Wang, F.; Zhou, J.; Zhang, Z. Selection of reliable reference genes for gene expression studies in peach using real-time PCR. BMC Mol. Biol. 2009, 10. [CrossRef] [PubMed]

56. Chang, E.; Shi, S.; Liu, J.; Cheng, T.; Xue, L.; Yang, X.; Yang, W.; Lan, Q.; Jiang, Z. Selection of reference genes for quantitative gene expression studies in Platycladus orientalis (Cupressaceae) using real-time PCR. PLoS ONE 2012, 7. [CrossRef] [PubMed]

57. Jian, B.; Liu, B.; Bi, Y.; Hou, W.; Wu, C.; Han, T. Validation of internal control for gene expression study in soybean by quantitative real-time PCR. BMC Mol. Biol. 2008, 9, 59. [CrossRef] [PubMed]

58. Li, Z.; Lu, H.; He, Z.; Wang, C.; Wang, Y.; Ji, X. Selection of appropriate reference genes for quantitative real-time reverse transcription PCR in Betula platyphylla under salt and osmotic stress conditions. PLoS ONE 2019, 14, e225926. [CrossRef]

59. Huang, L.; Yan, H.; Jiang, X.; Zhang, X.; Zhang, Y.; Huang, X.; Zhang, Y.; Miao, J.; Xu, B.; Frazier, T.; et al. Evaluation of candidate reference genes for normalization of quantitative RT-PCR in switchgrass under various abiotic stress conditions. BioEnergy Res. 2014, 7, 1201-1211. [CrossRef]

60. Gimenez, M.J.; Piston, F.; Atienza, S.G. Identification of suitable reference genes for normalization of qPCR data in comparative transcriptomics analyses in the Triticeae. Planta 2011, 233, 163-173. [CrossRef]

61. Paolacci, A.R.; Tanzarella, O.A.; Porceddu, E.; Ciaffi, M. Identification and validation of reference genes for quantitative RT-PCR normalization in wheat. BMC Mol. Biol. 2009, 10, 11. [CrossRef] [PubMed]

62. Carvalho, K.; de Campos, M.K.F.; Pereira, L.F.P.; Vieira, L.G.E. Reference gene selection for real-time quantitative polymerase chain reaction normalization in "Swingle" citrumelo under drought stress. Anal. Biochem. 2010, 402, 197-199. [CrossRef] [PubMed]

63. Long, X.Y.; Wang, J.R.; Ouellet, T.; Rocheleau, H.; Wei, Y.M.; Pu, Z.E.; Jiang, Q.T.; Lan, X.J.; Zheng, Y.L. Genome-wide identification and evaluation of novel internal control genes for Q-PCR based transcript normalization in wheat. Plant Mol. Biol. 2010, 74, 307-311. [CrossRef] [PubMed]

64. Reid, K.E.; Olsson, N.; Schlosser, J.; Peng, F.; Lund, S.T. An optimized grapevine RNA isolation procedure and statistical determination of reference genes for real-time RT-PCR during berry development. BMC Plant Biol. 2006, 6, 27. [CrossRef] [PubMed]

65. Fadzillah, N.M.; Gill, V.; Finch, R.P.; Burdon, R.H. Chilling, oxidative stress and antioxidant responses in shoot cultures of rice. Planta 1996, 199, 552-556. [CrossRef]

66. Purev, M.; Kim, Y.; Kim, M.K.; Pulla, R.K.; Yang, D. Isolation of a novel catalase (Cat1) gene from Panax ginseng and analysis of the response of this gene to various stresses. Plant Physiol. Biochem. 2010, 48, 451-460. [CrossRef]

67. Xing, Y.; Jia, W.; Zhang, J. AtMEK1 mediates stress-induced gene expression of CAT1 catalase by triggering $\mathrm{H}_{2} \mathrm{O}_{2}$ production in Arabidopsis. J. Exp. Bot. 2007, 58, 2969-2981. [CrossRef]

(C) 2020 by the authors. Licensee MDPI, Basel, Switzerland. This article is an open access article distributed under the terms and conditions of the Creative Commons Attribution (CC BY) license (http://creativecommons.org/licenses/by/4.0/). 